\title{
Scientists appeal to revoke funding ban on embryo research
}

The congressionally imposed ban on US government funding of embryo research has come under attack from prominent American scientists who believe that lack of federal support prevents many of the nation's talented researchers from participating in one of the most promising avenues of biomedical research. Their unhappiness with the funding prohibition comes specifically in response to recent news that two privately funded teams have developed and grown human stem cells for the first time, one group using embryos as its source.

On December 2nd, the scientists involved in the work-JamesThomson, of the University of Wisconsin's primate research center, and John Gearhart, of Johns Hopkins University School of M edicine-and National Institutes of Health Director Harold Varmus took their case to Capitol Hill. Government funding of research using embryos is essential if such work is to continue at a rapid pace, the researchers told members of the Senate Appropriations subcommittee on Labor, Health and Human Services and Education.

The ban was first imposed by Congress in 1995, and was renewed in legislation signed by President Clinton only weeks before the stem cell results were announced. Clinton lifted a ban on federal funding of research using fetal cellsin 1993 that was first imposed by Ronald Reagan, but cannot lift the embryo research ban as it was enacted through congressional legislation.

Embryonic stem cells used for experimentation are derived from the blastocyst of embryos produced but not used for in vitro fertilization (IVF). They result from the early division of a newly fertilized egg and have the capacity to form any cell or tissue in the body, which is why scientists are attempting to gain control over their development in vitro. Although federal funding for Gearhart's work is not prohibited, because his team uses material from pregnancy termination rather than IVF blastocysts, he is keen for the ban to be lifted so the field can progress.

While Varmus was careful to point out that $\mathrm{NIH}$ has adhered to the law and will continue to do so, he described the magnitude of the recent breakthrough in unusually enthusiastic terms, implying that federal support could give it an even further boost. "It is not too unrealistic to say that this research has the potential to revolutionize the practice of medicine and improve the quality and length of life," he said.

Thomson agreed: "How soon such therapies will be developed will depend on whether there is public support of research in this area. Privatecompanies will havean important rolein bringing new embryonic stem cell-related therapeutics to the marketplace; however, the current ban ... discourages the majority of the best US researchers from advancing this promising area of medical research."

Even officials from Geron, the private company that funded the recent work, argued that $\mathrm{NIH}$ should be

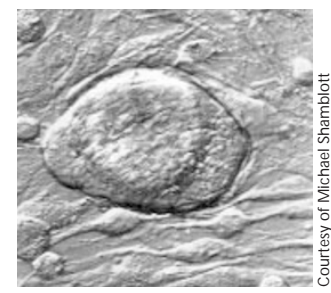

Human pluripotent stem cell colony strongly as I ever did that an embryo is still alife," and has vowed to fight any attempts to reverse the ban. And Henry Waxman (D-CA), who led an unsuccessful congressional fight some years ago to restore federal funding for fetal tissueresearch, isworried that some Republican leaders may seek to impose an even broader ban-both public and private, much as they tried but failed to do with human cloning research last year.

The next stage of the debate is likely to revolve around a report on the issue by the National Bioethics Advisory Commission which is expected in spring.

involved. Thomas Okarma, Geron's vice president of $R \& D$, said: "M uch of thisfrontier is early, basic research that will otherwise be underfunded by the private sector, thereby delaying and reducing the full impact of this discovery."

Senator Tom Harkin (D-IA), cited the law's specific wording. The term human embryo includes "any organism not protected as a human subject," and Harkin asked Congress to consider whether the cells alone could be defined as "organisms." NIH lawyers arestudying the law to find a loophole that will enable researchers to study stem cells and stay within legal boundaries.

Thefight has becomethelatest example of the tension between politics and science, in which researchers resent the interference of politicians, yet remain dependent on their financial generosity.

Congressional sponsors of the ban, which includeJay Dickey, (R-ARK), oppose embryo research because they believe it is the taking of a human life, much likeabortion. Dickey said recently, "I feel just as

Meanwhile, a joint report by theHuman Genetics Advisory Commission and the Human Fertilisation and Embryology Authority in the UK issued on December 8th, reiterates calls for a government ban on human cloning, but suggests an expansion of "the purposes for which embryo research can becarried out under closeregulation," given the new advances in stem cell research. The law now permits use of embryos up to 14 days old for fertility research only. The proposal means that embryos could be used for other types of medical research, such astissuegeneration. A copy of the report, Cloning Issues in Reproduction, Science and Medicine is available at http://www.dti.gov.uk/hgac/

A European Union (EU) ethics advisory group that met six weeks ago also concluded that whereas research on human embryos should be strictly controlled, it should not bebanned. The panel said that their decision reflects the diverse attitudes to embryo research within Europe.

Marlene Cimons, Washington, D.C.

\& Karen Birmingham, New York

\section{AMDeC announces New York Cancer Project}

Twenty-five medical schools and academic research centers in New York State are collaborating on a cancer research project under the aegis of a new consortium called the Academic Medicine Development Company (AMDeC). The project is supported by $\$ 6$ million funding in its first year and aims to advance epidemiological understanding of genetic and environmental causes of cancer. The work will be carried out in two phases: a pilot study beginning this spring will recruit 5,000 New Yorkers between the ages of 35 and
64 for study over a two-year period. Thereafter, 300,000 people will be monitored and evaluated over a 20-year period.

AMDeC member institutions include Albert Einstein Medical College, Beth Israel Medical Center, Memorial Sloan-Kettering, NYU Medical Center and Rockefeller University. Arnold Levine, president of Rockefeller and head of the AMDeC scientific advisory committee, says the consortium has been formed to "re-invigoratetheCity's biomedical research institutions."

Karen Birmingham, New York 